\title{
Whitening Effects of Solvent Fractions Isolated from Vitex rotundifolia
}

\author{
Jae-Myo Yu · Dong-Hee Kim · Jun-Ho Son* (i) \\ 만형자 용매 분획물의 미백 개선 효과
}

유재묘 · 김동희 · 손준호*

Received: 11 June 2015 / Accepted: 17 July 2015 / Published Online: 30 September 2015

(C) The Korean Society for Applied Biological Chemistry 2015

\begin{abstract}
Recently many effort focused to understand the mechanical insights of melanogenesis to develop the agent for hyper-pigmentation. So this study was performed to investigate the depigmentation of Vitex rotundifolia. With B16F10 mouse melanoma cell, we have seen inhibition of the tyrosinase, MITF, TRP-1, TRP-2, and melanin synthesis, which eventually were dose dependently decreased by Vitex rotundifolia. Specially, Vitex rotundifolia decreased the protein levels of tyrosinase and TRP-1. In conclusion, Vitex rotundifolia showed the whitening activity in all the experiments mentioned above and we expect that it can be used for preventing melanin synthesis.
\end{abstract}

Keywords inhibition of melanin $\cdot$ TRP-1 tyrosinase $\cdot$ Vitex rotundifolia $\cdot$ whitening effect

\section{서 론}

현대에 있어서 깨끗하고 하얀 피부는 아름다움의 척도가 되었 다. 특히 생활수준의 향상과 수명의 연장으로 피부미용에 대한 관심이 증가되었고, 환경오염에 따른 자외선 노출증가로 인해 피부 미백에 대한 관심을 더욱 커지게 하였다. 이에 따라 피부

J.-M. Yu $\cdot$ D.-H. Kim · J.-H. Son

Korea Promotion Institute for Traditional Medicine Industry, Gyeongsan 712-260, Republic of Korea.

*Corresponding author (J.-H. Son: bio115@kotmin.kr)

This is an Open Access article distributed under the terms of the Creative Commons Attribution Non-Commercial License (http://creativecommons. org/licenses/by-nc/3.0/) which permits unrestricted non-commercial use, distribution, and reproduction in any medium, provided the original work is properly cited.
에 안정적이고 자극이 없는 미백소재를 찾는 연구가 활발하게 진행되고 있다(Lee 등, 2003).

피부 미백에 대한 연구는 tyrosinase의 활성 억제, 3,4-dihydroxyphenylalanine (DOPA) 산화 억제, 자외선 차단 등에 대해서 행 해지고 있는데 keratinocyte에 있는 멜라닌의 양과 분포에 따라 피부색 및 색소침착이 결정되기 때문에 미백효과를 검증하기 위 해서는 멜라닌 형성을 억제하는지를 확인하는 것이 중요하다 (Cho 등, 2003).

멜라닌은 피부가 자외선에 노출되었을 때 melanocyte의 melanosome에서 tyrosine이 tyrosinase라는 효소에 의해 산화되 어 생성되는데 이때 tyrosinase의 합성 및 전달에 관여하는 dopachrome tautomerase, peroxidase, catalase, glutathione reductase 등의 효소와 interferon, prostaglandin, cyclooxygenase 등과 같은 mediator 및 구리, 아연 철과 같은 금속이온이 관여 하는 것으로 알려져 있다(Park 등, 2004b). 멜라닌은 자연계에 널리 분포하는 페놀류의 고분자 물질로서 단백질과 검은 색소 의 복합체이다. 이것은 인체내에서 독성물질에 대한 제거 작용 을 하여 세포를 보호한다. 하지만 과잉 생산시 인체에 기미, 주 근깨를 형성하고 피부 노화를 촉진시키며 피부암을 유발하는 것 으로 알려져 있다. 이러한 멜라닌의 생합성 경로를 보면 tyrosine 이 tyrosinase에 의해서 $\mathrm{DOPA}$ 로 전환되고 다시 tyrosinase에 의 해 DOPA quinone으로 전환되어 최종적으로 멜라닌을 생성하 게 된다(Hearing, 1999; Hwang 과 Lee, 2007). 이에 따라 멜 라닌의 생합성을 억제하는 물질을 찾아내어 미백효과 등의 효 능을 확인하는데 적용시킬 수 있다(Mauviel 등, 1994; Pentland 등, 1995; Park 등, 2004a).

만형자(Vitex rotundifolia)는 순비기나무(Vitex rotundifolia L.) 의 성숙된 열매를 건조한 것으로 마편초과(Verbenaceae)에 속하 는 약용식물자원이며 우리나라 중부이남의 섬이나 해안가에 자 생하는 것으로 알려져 있다(Lee, 1993; Yeeh 등, 1996). 또한 진통, 진정, 소염의 목적으로 만성중이염, 습진, 이명, 난청, 두 통, 신경통 등에 사용되어온 생약으로(Perry, 1980; Encyclopedia of Chinese herbal medicine, 1985), 동의보감에는 풍두통(風頭 
痛)과 뇌명(腦鳴)에 달여 먹는다고 기술되어 있다(Heo, 1991). 만형자에 관한 연구로는 약 76 종의 정유성분 및 monoterpene 류(Jang 등, 2002), flavonoids, phenol 화합물 등이 분리된 바 있으며(Kang 등, 1994; Yoshioka 등, 2004), 또한 만형자는 모 발성장 촉진 효과(Shin 등, 2009), 염증 및 알레르기 반응(Yeon 등, 2013) 등에 효능을 나타내는 것으로 알려져 있다.

본 연구에서는 $\mathrm{B} 16 \mathrm{~F} 10$ mouse melanoma cell을 이용하여 예 로부터 한방생약재로 사용하며 유용한 성분 및 효과를 나타내 는 만형자 용매 분획물을 처리한 후 melanin 정량과 western blotting으로 MITF, tyrosinase, TRP-1, TRP-2 등의 단백질 발 현을 확인하여 미백효과에 대한 효능을 검증하였다.

\section{재료 및 방법}

시료. 본 실험에 사용한 만형자는 2014년 2월 초순에 (주)휴먼 허브(Korea)에서 구입하여 시료로 사용하였다.

시료 추출 및 용매분획. 건조된 시료 $300 \mathrm{~g}$ 을 분쇄기를 이용하 여 잘게 파쇄한 후 $70 \%$ 에탄올을 $3 \mathrm{~L}$ 넣어 상온에서 24 시간 동 안 동일 용매로 3회 반복 추출한 다음 filter paper (Whatman No. 2, Japan)로 여과한 뒤 감압농축기로 에탄올을 제거하여 농 축액 $7.24 \mathrm{~g}$ 을 얻었다. 이후 용매추출법을 이용하여 극성도가 낮 은 $n$-hexane으로 추출한 후, 다시 ethyl acetate와 butanol로 순 차적으로 분획하였다. 각 용매 추출 분획을 freeze drier (Ilsin, Korea)로 감압 농축하여 $n$-hexane (VR-H) $0.65 \mathrm{~g}$, EtOAc (VREA) $1.21 \mathrm{~g}, \mathrm{n}-\mathrm{BuOH}$ (VR-B) $1.56 \mathrm{~g}, \mathrm{H}_{2} \mathrm{O}$ (VR-W) $1.02 \mathrm{~g}$ 을 각각 얻었다.

시약 및 기기. 미백 효과 측정에 사용된 시약인 L-ascorbic acid, L-3,4-dihydroxyphenylalanine (L-DOPA) 등은 Sigma chemical Co. (USA)에서 구입하여 사용하였다. 세포 독성 측정에 사용된 세포주는 mouse melanoma cell인 B16F10을 Korean cell line bank (Korea)에서 구입하여 사용하였다. 세포 독성 측정 시약은 dulbecco's modified eagle medium (DMEM), fetal bovine serum (FBS), penicillin/streptomycin, $0.25 \%$ trypsin-EDTA, $0.4 \%$ trypan blue stain은 Gibco BRL Co. (USA) 및 haemacytometer (Marienfeld, Germany)에서 구입하여 사용하였으며, 3-[4,5-dimethylthiazol-2yl]-2,5-diphenyl-tetrazolium bromide (MTT)는 Sigma chemical Co. (USA)에서 구입하여 사용하였다. 1차 항체인 tyrosinase, MITF, tyrosinase-related protein (TRP)-1, TRP-2와 2차 항체는 Santa cruz biotechnology Inc. (USA)에서 구입하였다. 실험에 사용한 기기는 ELISA reader (Tecan, Switzerland), rotary vaccum evaporator (Rikakikai Co., Japan), centrifuge (Eppendorf, Germany), $\mathrm{CO}_{2}$ incubator (Hanbaek, Korea)를 사용하였다.

세포배양. 본 실험에 이용한 각 세포의 배양은 $10 \% \mathrm{FBS}$ 와 $1 \%$ penicillin/streptomycin $(100 \mathrm{U} / \mathrm{mL})$ 을 첨가한 $\mathrm{DMEM}$ 배지를 사 용하였으며, $37^{\circ} \mathrm{C}, 5 \% \mathrm{CO}_{2}$ incubator에 적응시켜 계대 배양하 였다. 세포 확인시 inverted microscope (Nikon, Japan)를 사용 하였다. B16F10 mouse melanoma cell에 시료용액을 농도별로 1 시간 전처리한 후 $\alpha$-melanocyte stimulating hormone ( $\alpha-\mathrm{MSH})$ $10 \mathrm{nM}$ 를 48시간 처리하였다.

MTT assay에 의한 세포 독성 측정. 세포 독성 측정은 Carmichael 등(1987)의 방법에 따라 측정하였다. $\mathrm{B} 16 \mathrm{~F} 10$ mouse melanoma cell을 96 well plate에 $1 \times 10^{3}$ cells/well이 되
게 $0.18 \mathrm{~mL}$ 분주하고, 시료를 농도별로 조제하여 $0.02 \mathrm{~mL}$ 첨가 한 후 $37^{\circ} \mathrm{C}, 5 \% \mathrm{CO}_{2}$ incubator에서 48 시간 처리하였다. 대조 군은 시료와 동량의 증류수를 첨가하여 동일한 조건으로 배양 하였다. 여기에 $5 \mathrm{mg} / \mathrm{mL}$ 농도로 제조한 MTT 용액 $0.02 \mathrm{~mL}$ 를 첨가하여 4시간 배양한 후 배양액을 제거하고 각 well에 DMSO $0.15 \mathrm{~mL}$ 를 가하여 실온에서 30 분간 반응 시킨 뒤 ELISA reader로 $540 \mathrm{~nm}$ 에서 흡광도를 측정하였다. 세포 독성 측정은 시료용액의 첨가군와 무첨가군의 흡광도 감소율로 나타 내었다.

Melanin 정량. 멜라닌 양은 Hosoi 등(1985)의 방법을 변형하여 사용하였다. B16F10 mouse melanoma cell를 6 well에 $5 \times 10^{4}$ cells/well이 되도록 분주하여 24시간 뒤, 각각의 well에 VR-EA, VR-H, VR-B, VR-W $25 \mu \mathrm{g} / \mathrm{mL}$ 와 사용전에 제조한 vitamin C (Vit. C; Sigma, USA) $25 \mu \mathrm{g} / \mathrm{mL}$ 를 48시간 동안 처리하였다. 처리 후 phosphate buffered saline (PBS; Gibco, USA)로 2회 세척한 후 $12,000 \mathrm{rpm}, 4^{\circ} \mathrm{C}, 30$ 분간 원심 분리하여 세포 침전 물을 만들었다. $10 \%$ dimethyl sulfoxide (DMSO; Duksan, Korea)가 첨가된 $1 \mathrm{~N} \mathrm{NaOH}$ 용액을 $150 \mu \mathrm{L}$ 첨가하고 $60^{\circ} \mathrm{C}$ 에서 1 시간 용해하였으며 $405 \mathrm{~nm}$ 에서 흡광도를 측정한 후 실험군의 멜라닌 양은 대조군의 멜라닌 양에 대한 백분율로 계산하여 나 타내었다.

Cellular tyrosinase 저해율 측정. Cellular tyrosinase 저해율 측정은 Choi 등(1998)의 방법을 변형하여 측정하였다. $\mathrm{B} 16 \mathrm{~F} 10$ mouse melanoma cell을 6 well plate에 $5 \times 10^{4}$ cells/well이 되도 록 접종하고 각 well에 VR-EA, VR-EA, VR-H, VR-B, VR-W 및 Vit. C $(25 \mu \mathrm{g} / \mathrm{mL})$ 를 48시간 동안 처리하였다. 처리 후 PBS 로 2회 세척한 후 각 well의 세포에 lysis buffer ( $1 \%$ triton X-100, $0.1 \mathrm{M}$ sodium phosphate buffer, $50 \mathrm{mM}$ phenylmethylsulfonyl fluoride, $\mathrm{pH}$ 6.8)를 가하였다. 얼음 위에서 세포를 파괴시키고 $12,000 \mathrm{rpm}, 4^{\circ} \mathrm{C}, 30$ 분간 원심 분리한 후 상층액만 따로 모아 효소용액으로 사용하였다. L-DOPA를 $2 \mathrm{mg} / \mathrm{mL}$ 농도로 $0.1 \mathrm{M}$ sodium phosphate buffer $(\mathrm{pH}$ 6.8)에 녹여 기질을 준비하고 기 질 $160 \mu \mathrm{L}$ 에 효소용액 $40 \mu \mathrm{L}$ 를 가하고 $37^{\circ} \mathrm{C}$ 에서 1 시간 가온하 고 생성된 DOPA chrome의 양을 $490 \mathrm{~nm}$ 에서 측정한 후 억제 율을 계산하였다.

Western blot을 통한 tyrosinase, MITF, TRP-1, TRP-2 단백 질의 발현 측정. $\mathrm{B} 16 \mathrm{~F} 10$ mouse melanoma cell을 6 well plate에 $5 \times 10^{4}$ cells/well에 되도록 분주하고 24 시간 동안 안정화 하였다. 배지를 제거한 후 VR-EA를 농도별로 $(5,10,20,25$ $\mu \mathrm{g} / \mathrm{mL}$ ) 48시간 처리 후 PBS로 세척하였다. Lysis buffer를 well 당 $30 \mu \mathrm{L}$ 를 첨가하여 세포를 용해시키고 원심분리하여 $\left(12,000 \mathrm{rpm}, 4^{\circ} \mathrm{C}, 30 \mathrm{~min}\right)$ 세포막 성분들을 제거하였다. 원심 분리하여 얻은 단백질은 bradford assay로 정량하였으며, $20 \mu \mathrm{L}$ 의 단백질을 $10 \%$ 의 sodium dodecyl sulfate polyacrylamide gel electrophoresis를 이용하여 전기 영동한 후, 항체의 비특이 적 결합을 억제시키기 위해 PVDF membrane에 옮긴 다음 60 $\mathrm{V}$ 에서 2시간 이상 transfer하였다. Transfer가 끝나면 5\% skim milk에 1 시간동안 방치하여 background를 제거시켰다. $1 \times \mathrm{TBST}$ 로 3회 washing 후 1차 antibody (1:1000)를 1시간 동안 붙인 후 다시 2차 antibody (1:1000)를 붙이고 ECL kit (Amersham Pharmacia, England)를 이용하여 film에 옮겨 측정하였다. Band density는 ImageQuant LAS-4000 (GE life sciences, Taiwan) 으로 확인하였다. 


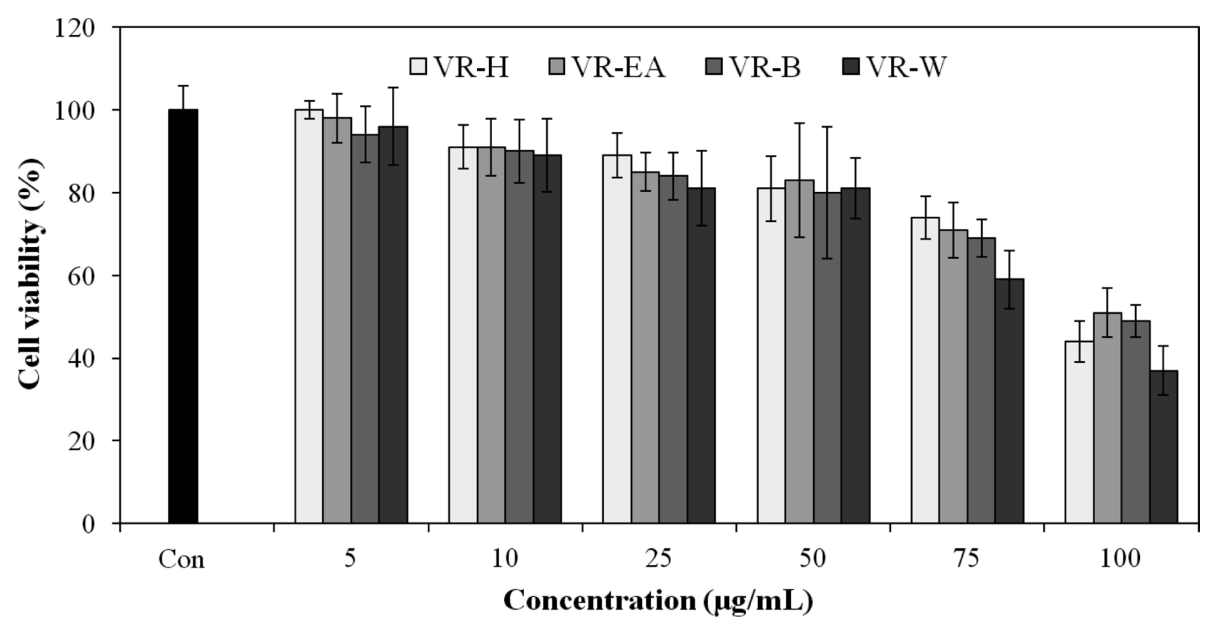

Fig. 1 Cytotoxicity of mouse melanoma cell (B16F10) of solvent fractions isolated from Vitex rotundifolia. VR-H: Vitex rotundifolia hexane fraction; VR-EA: Vitex rotundifolia ethyl acetate fraction; VR-B: Vitex rotundifolia butanol fraction; VR-W: Vitex rotundifolia water fraction; Con: $\alpha-M S H$ induced group. Result are means $\pm \mathrm{SD}$ of triplicate data.

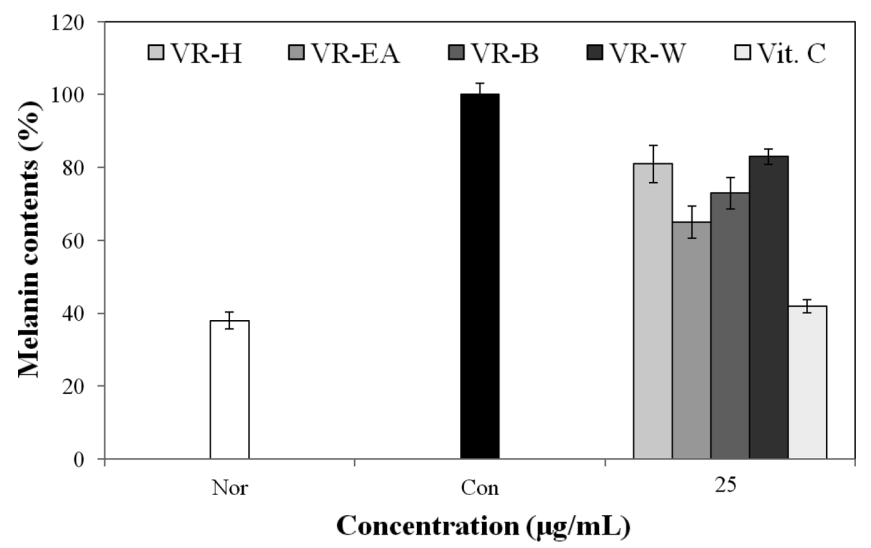

Fig. 2 Inhibition melanin synthesis of solvent fractions isolated from Vitex rotundifolia on mouse melanoma cell (B16F10). VR-H: Vitex rotundifolia hexane fraction; VR-EA: Vitex rotundifolia ethyl acetate fraction; VR-B: Vitex rotundifolia butanol fraction; VR-W: Vitex rotundifolia water fraction; Vit. C: L-ascorbic acid; Nor: $\alpha$-MSH not induced group; Con: $\alpha-\mathrm{MSH}$ induced group. Result are means $\pm \mathrm{SD}$ of triplicate data.

\section{결과 및 고찰}

MTT assay에 의한 세포 독성 측정. 만형자 분획물에 의한 $\mathrm{B} 16 \mathrm{~F} 10$ mouse melanoma cell의 독성을 확인하기 위해 분획물 을 적정 농도로 48시간 동안 처리한 후 MTT assay를 실시하 였다. 세포 독성은 VR-EA이 농도 $5,10,25 \mu \mathrm{g} / \mathrm{mL}$ 에서 각각 $98,91,85 \%$ 의 생존율을 보여 처리하지 않은 대조군에 비하여 세포 생존율이 크게 감소하지 않는 것으로 보아 세포에 대한 독성을 나타내지 않는 것을 확인할 수 있었다(Fig. 1).

Melanin 정량. 멜라닌은 동물, 식물, 미생물에 널리 분포하는 색소로서 사람의 경우 피부색을 결정하는 동시에 유해한 자외 선이나 유리기(free radical)로부터 인체를 보호하는 역할을 담당 하고 있다. 이 색소는 피부의 기저층에 존재하는 멜라닌 생성 세포가 자외선 및 자극에 의해 활성화되어 만들지고 표피의 가 장 위층인 각질층에 존재한다. 멜라닌 색소의 생합성은

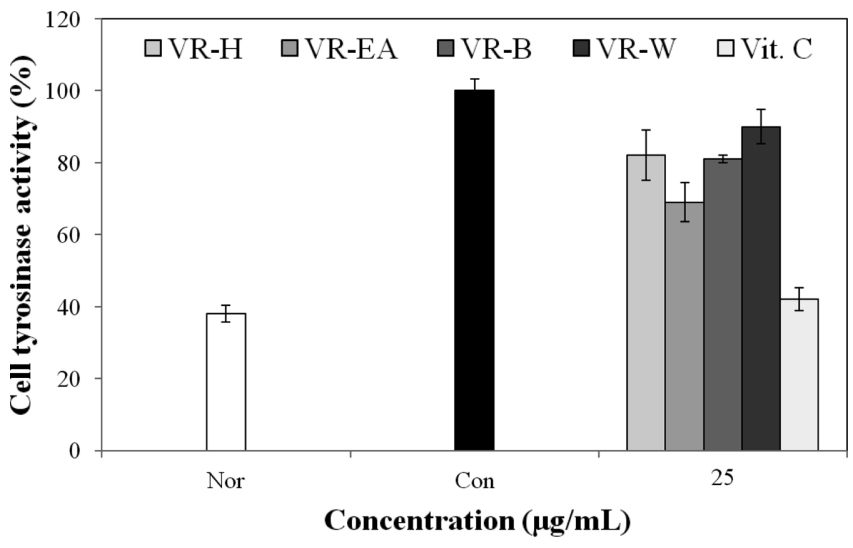

Fig. 3 Inhibition cellular tyrosinase of solvent fractions isolated from Vitex rotundifolia on mouse melanoma cell (B16F10). VR-H: Vitex rotundifolia hexane fraction; VR-EA: Vitex rotundifolia ethyl acetate fraction; VR-B: Vitex rotundifolia butanol fraction; VR-W: Vitex rotundifolia water fraction; Vit. C: L-ascorbic acid; Nor: $\alpha$-MSH not induced group; Con: $\alpha-\mathrm{MSH}$ induced group. Result are means $\pm \mathrm{SD}$ of triplicate data.

tyrosinase 효소를 비롯하여 다양한 효소들에 의해 조절되고 있 는 것으로 알려져 있다(Aroca 등, 1993; Paval, 1993; JimenezCervantes 등, 1994). 색소 침착을 치유하기 위해 멜라닌 생성 을 억제하는 페놀 유도체나 kojic acid, arbutin, glucosamine 등이 개발되어 있으나, 피부에 대한 자극이나 안정성에 문제가 있어서 제한된 양만 사용되고 있다.

멜라닌 생합성 저해 정도를 확인한 결과, Vit. C의 경우 25 $\mu \mathrm{g} / \mathrm{mL}$ 를 처리하였을 때 멜라닌을 $58 \%$ 저해하였으며, 만형자 분획물의 경우 VR-EA, VR-B, VR-H, VR-W의 순서로 높게 나타났고 각각 $35,27,19,17 \%$ 의 억제 효과를 보였다(Fig. 2). 반면에 삼백초 에탄올 추출물은 동일한 농도에서 약 $21 \%$ 의 억 제 효과를 나타내어(Park과 Lee, 2008) VR-H, VR-W 보다는 높은 효과를 보였지만 VR-EA, VR-B의 효과에는 미치지 못하 였다.

Cellular tyrosinase 저해율 측정. 멜라닌 생성에 있어서 가장 


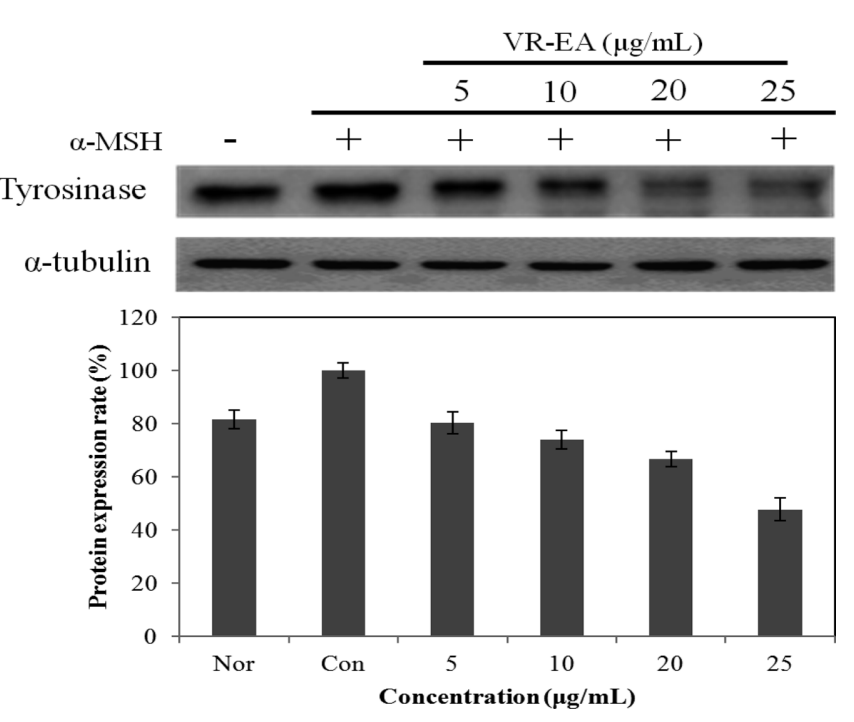

Fig. 4 Tyrosinase protein expression rate of ethyl acetate fraction isolated from Vitex rotundifolia on mouse melanoma cell (B16F10). Lysates were prepared from control or different concentration $(5,10,20,25 \mu \mathrm{g} / \mathrm{mL})$ of VR-EA. Nor: $\alpha$-MSH not induced group. Con: $\alpha-\mathrm{MSH}$ induced group. Result are means \pm SD of triplicate data.

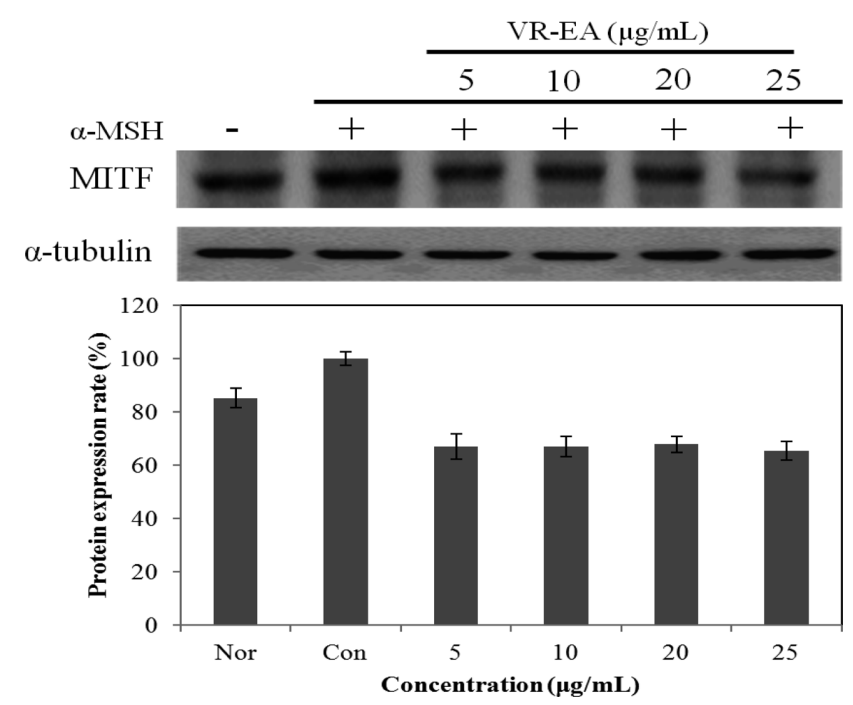

Fig. 5 MITF protein expression rate of ethyl acetate fraction isolated from Vitex rotundifolia on mouse melanoma cell (B16F10). Lysates were prepared from control or different concentration $(5,10,20,25 \mu \mathrm{g} / \mathrm{mL})$ of VR-EA. Nor: $\alpha$-MSH not induced group. Con: $\alpha-\mathrm{MSH}$ induced group. Result are means \pm SD of triplicate data.

중요한 역할을 하는 효소는 tyrosinase로서 melanosome 내의 tyrosine을 산화시켜 DOPA, DOPA quinone으로 바뀌고, 이들은 효소의 작용 및 자동 산화 반응에 의해 DOPA chrome, indole carboxylic acid, indole quinine 등으로 대사되어 최종적으로 멜 라닌을 합성한다(Lin 등, 2002). 따라서 피부 내에서 멜라닌 중 합체 생합성을 효과적으로 저해할 수 있는 tyrosinase 저해활성 을 측정하기 위하여 cellular tyrosinase 활성 측정 결과, 모든 분획물에서 tyrosinase 저해효과를 보여주었다. VR-EA는 $25 \mu \mathrm{g}$ / $\mathrm{mL}$ 에서 $31 \%$ 의 저해능을 나타낸 반면, Vit. C는 $25 \mu \mathrm{g} / \mathrm{mL}$ 에서
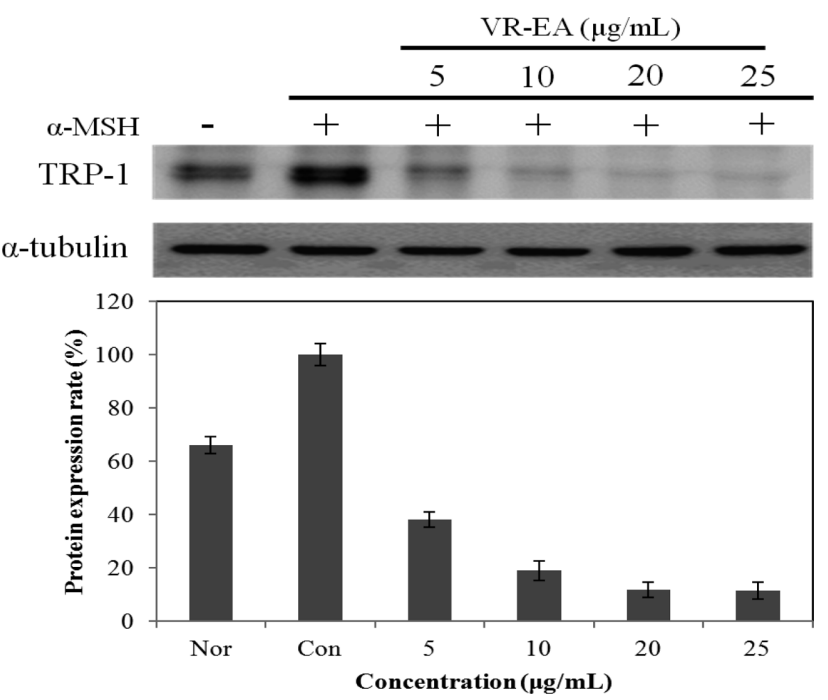

Fig. 6 TRP-1 protein expression rate of ethyl acetate fraction isolated from Vitex rotundifolia on mouse melanoma cell (B16F10). Lysates were prepared from control or different concentration $(5,10,20,25 \mu \mathrm{g} / \mathrm{mL})$ of VR-EA. Nor: $\alpha$-MSH not induced group. Con: $\alpha-M S H$ induced group. Result are means \pm SD of triplicate data.

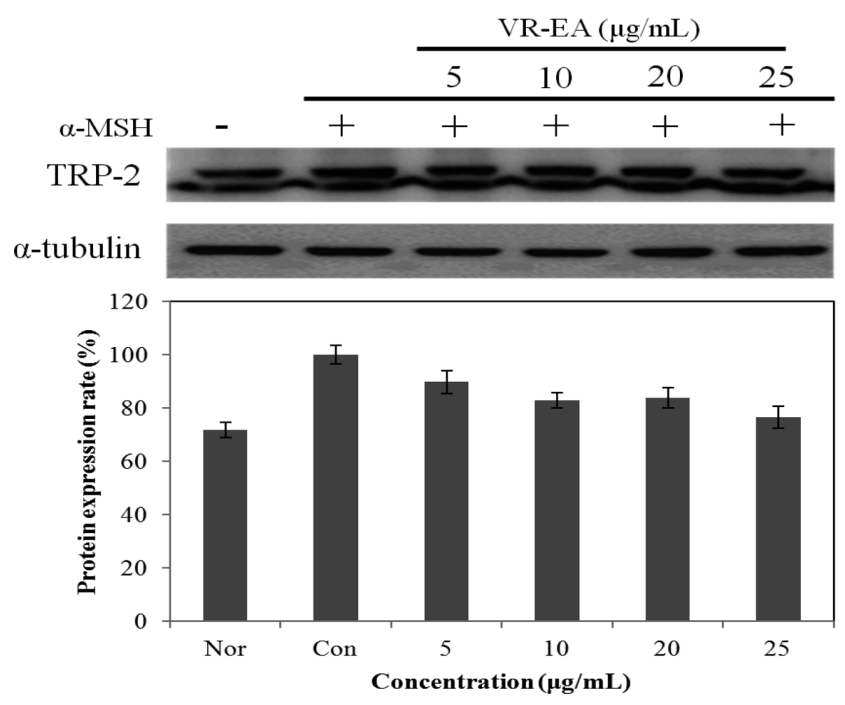

Fig. 7 TRP-2 protein expression rate of ethyl acetate fraction isolated from Vitex rotundifolia on mouse melanoma cell (B16F10). Lysates were prepared from control or different concentration $(5,10,20,25 \mu \mathrm{g} / \mathrm{mL})$ of VR-EA. Nor: $\alpha-\mathrm{MSH}$ not induced group. Con: $\alpha-\mathrm{MSH}$ induced group. Result are means $\pm \mathrm{SD}$ of triplicate data.

$58 \%$ 의 저해능을 나타내었으며 VR-B는 $19 \%, \mathrm{VR}-\mathrm{H}$ 는 $18 \%$ 그 리고 VR-W의 경우 $10 \%$ 의 저해 효과를 보여주었다(Fig. 3). 동 일한 실험에서 감귤 추출물 $(70 \% \mathrm{EtOH})$ 의 경우 같은 농도에서 약 $4 \%$ 의 효과를 나타내어 $(\mathrm{Kim}$ 등, 2007) 상대적으로 효능이 뛰어난 것을 알 수 있었다.

Western blot을 통한 tyrosinase, MITF, TRP-1, TRP-2 단백 질의 발현 측정. $\alpha-\mathrm{MSH}$ 는 tyrosinase의 활성을 자극시키고 (Abdel-Maldk 등, 1995), 멜라닌 합성에 관여하는 효소인 TRP1, TRP-2에 작용하여 eumelanin을 합성하도록 유도한다(Fuller 
와 Meyskens, 1981). TRP-1은 DHICA를 indole-5,6-carboxylic acid로 전환시키는 효소로서 DHICA oxidase라고도 하며 tyrosinase의 변성을 막는데 작용하여 tyrosinase의 활성에 기여 하는 효소로 간접적으로 멜라닌 생성을 조절한다(Hearing 등, 1992; Takechi 등, 1996). 따라서 미백소재의 개발에 있어서 멜 라닌 생성을 억제하는 기전과 이미 생성된 멜라닌의 분해를 촉 진시키는 단계에서 작용하는 효소의 조절이 중요하며 멜라닌 생 성에 관련된 단백질 발현과 연관성이 있는지 보기 위해 tyrosinase, MITF, TRP-1, TRP-2의 항체를 이용한 western blotting으로 관 련 단백질의 발현양 변화에 대하여 확인하였다. B16F10 mouse melanoma cell에 VR-EA를 $5,10,20,25 \mu \mathrm{g} / \mathrm{mL}$ 처리 한 후 48시간 뒤에 tyrosinase, MITF, TRP-1, TRP-2 protein 발현을 western blotting으로 확인 하였다. 또한 세포에서 발현 정도의 차이가 거의 없는 house keeping gene인 $\alpha$-tubulin을 이용하여 tyrosinase, MITF, TRP-1, TRP-2 protein을 정량하였다. VR$\mathrm{EA}$ 를 농도 별로 처리하였을 때 $25 \mu \mathrm{g} / \mathrm{mL}$ 을 처리한 군에서는 tyrosinase protein이 $53.2 \%$ 감소하였고, MITF는 $34.7 \%$, TRP1 은 $88.4 \%$, TRP-2의 경우 $23.6 \%$ 의 감소율을 보여 주었다(Fig. 4-7). 상대적으로 노간주나무 추출물 $(70 \% \mathrm{EtOH})$ 은 동일 농도에 서 tyrosinase, MITF, TRP-1, TRP-2의 순서로 약 $12,10,9$, $17 \%$ 의 효과를 나타내어(Lee 등, 2013) VR-EA보다 protein 발 현의 억제율이 낮게 나타났다.

\section{초 록}

최근에는 hyper-pigmentation에 대한 제품 개발을 위해 melanogenesis 의 경로에 대한 이해를 위해 많은 노력을 하고 있다. 이에 따 라 본 연구에서는 만형자(Vitex rotundifolia)의 depigmentation에 대한 효과를 조사하였다. B16F10 mouse melanoma cell을 이 용하여 tyrosinase, MITF, TRP-1, TRP-2 그리고 melanin synthesis의 저해를 확인하였고, 만형자 ethyl acetate 분획물(VR$\mathrm{EA})$ 을 처리하였을 때 농도의존적으로 감소한다는 것을 알 수 있었다. 특히, VR-EA는 tyrosinase와 TRP-1의 경우 각각 53.2, $88.4 \%$ 의 저해율을 보여 미백에 있어서 효과적인 활성을 보여주 었다. 따라서 만형자는 melanin synthesis를 효과적으로 막아주 어 미백소재로서 활용 가능성이 충분하다고 사료된다.

Keywords 만형자·미백효과·멜라닌형성저해·TRP-1·tyrosinase

감사의 글 이 연구는 산업통상자원부 지역연고산업육성사업(R0002128, 경 북화장품산업육성사업)의 일환으로 수행하였음.

\section{References}

Abdel-Maldk ZA, Swope NB, Suzuki I, Harriger D, Boyce ST, Urabe K et al (1995) Mitogenic and melanogenic stimulation of normal human melanocytes by melanotropic peptides. PRoc Natl Acad Sci 92, 1789-93.

Aroca P, Urabe K, Kobayashi K, Taskamoto K, and Hearing VJ (1993) Melanin biosynthesis patterns of following hormonal stimulation. $J$ Biol Chem 268, 25650-5.

Carmichael J, DeGraff WG, Gazdar AF, Minna JD, and Mitchell JB (1987) Evaluation of a tetrazolium based semiautomated colorimetric assay: assessment of chemosen- sitivity testing. Cancer Res 47, 936-42.
Cho JH, Kim HJ, and Kim YB (2003) The study on depigmentation effects of salt, acetum, sesami semen nigrum. J Korean Med Ophthalmol Otolaryngol Dermatol 16, 79-95.

Choi BW, Lee BH, Kang KJ, Lee ES, and Lee NH (1998) Screening of the tyrosinase inhibitors from marine algae and medicinal plants. Kor $J$ Pharmcogn 29, 237-42.

Encyclopedia of Chinese herbal medicine (1985) Shanghai Science technology publishing house, China.

Fuller BB and Meyskens FL Jr (1981) Endocrine responsiveness in human melanocyte and melanoma cell in culture. J Natl Cancer Inst 66, 799802.

Hearing VJ (1999) Biochemical control of melanogenesis and melanosomal organization. J Investig Dermatol Symp Proc 4, 24-8.

Hearing VJ, Tsukamoto K, Urabe K, Kameyama K, Montague PM, and Jackson IJ (1992) Fuctional properties of cloned melanogenic proteins. Pigment Cell Res 5, 264-70.

Heo J (1991) In Donguibogam, Namsandang, Korea.

Hosoi J, Abe E, Suda T, and Kuroki T (1985) Regulation of melanin synthesis of B16 melanoma cell by 1 alpha, 25-dihydroxyvitamin D3 and retinoic acid. Cancer Res 45, 1474-8.

Hwang J and Lee BM (2007) Inhibitory effects of plant extracts on tyrosinase, L-DOPA oxidation, and melanin synthesis. $J$ Toxicol Environ Health A70, 393-407.

Jang SJ, Kim YH, Kim MK, Kim KW, and Yun SE (2002) Essential oil composition from leaves, flowers, stems, and fruits of Vitex rotundifolia L. fil. J Korean Soc Agric Chem Biotechol 45, 101-7.

Jimenez-Cervantes C, Solano F, Kobayashi T, Urabe K, Hearing VJ, Lozano J et al. (1994) A new enzymatic fuction in the melanogenic pathway. $J$ Biol Chem 269, 17993-8001.

Kang SS, Kim JS, Kim HJ, and Jung YR (1994) Phytochemical analysis of Viticis Fructus. Kor J Pharmacogn 25, 214-20.

Kim HS, Lee CW, Kim DH, Kim GO, Kim SJ, and Chang IS (2007) The study on the whitening effects and antioxidant activity of various citrus fruits. J Soc Cosmat Korea 33, 69-77.

Lee SY, Jun HJ, Lee IC, and Lee JY (2013) Down-regulation of Tyrosinase, MITF, TRP-1, and TRP-2 Expressions by Juniperus rigida Sieb. in Murine B16F10 Melanoma. J Life Science 23, 1445-53.

Lee TB (1993) In illustrated flora of Korea. Hyangmoonsa, Korea.

Lee TH, Kim HJ, and Kim YB (2003) Depigmentation activity of barley, unpolished rice, Job's-tear. J Korean Med Ophthalmol Otolaryngol Dermatol 16, 57-78.

Lin CB, Babiarz L, Liebel F, Roydon-Price E, Kizoulis M, Gendimenico GJ et al. (2002) Modulation of microphtalmia-associated transcription factor gene expression alters skin pigmentation. J Invest Dermatol 119, 1330 40.

Mauviel A, Halcin C, Vasiloudes P, Parks WC, Kurkinen M, and UittoJ (1994) Uncoordinate regulation of collagenase, stromelysin, and tissue inhibitor of metalloproteinases genes by prostaglandin E2; Selective enhancement of collagenase gene expression in human dermal fibroblasts in culture. $J$ Cell Biochem 54, 465-72.

Park DJ and Lee JC (2008) A study on the antioxidative and depigmentation activities of the ethanol extract of Saururus herba. Korean J Herb 23, 193-202.

Park JH, Shin YG, Shin UK, Baek SK, Lee SK, Chung MH et al. (2004a) Tyrosinase inhibition activity of some herbal drug. Yakhak Hoiji 41, 418.

Park SK, Kim SN, Lee JC, Kim HS, Kim YJ, Lee BG et al. (2004b) Antiaging effects on skin with jaeum-Dam (JED). Korean J Herb 19, 67-76.

Paval S (1993) Dynamics of melanogenesis intermediates. J Invest Dermatol 100, $162 \mathrm{~S}-5 \mathrm{~S}$.

Pentland AP, Shapiro SD, and Welrus HG (1995) Agonist-induced expression of tissue inhibitor of metalloproteinases and metalloproteinases by human macrophages is regulated by endogenous prostaglandin E2 synthesis. J Invest Dermatol 104, 52-7.

Perry LM (1980) In Medicine plants of east and southeast asia, attributted properties and uses. MIT, UK.

Shin HS, Lee KJ, and Yi TH (2009) Effect of vitex rotundifolia on hair regeneration : in vitro and in vivo study. J Invest Cosmetol 5, 1-5.

Takechi Y, Hera I, Naftzer C, Xu Y, and Houghton AN (1996) A 
melanosomal membrane protein is a cell surface tarket for melanoma therapy. Clin Cancer Res 2, 1837-42.

Yeeh Y, Kang SS, Chung HG, and Chung MS (1996) Genetic and clonal diversity in Korean populations of Vitex rotundifolia (Verbenaceae). $J$ Plant Research 109, 161-8.

Yeon KJ, Jung HA, and Roh SS (2013) The Effects of Vitex rotundifolia
Linne fil. Extract on the Inflammatory and Allergic Reactions. Daejeon journal of the institute of oriental medicine 22, 145-70.

Yoshioka T, Inokuchi T, Fujioka S, and Kimura Y (2004) Phenolic compounds and flavonoids as plant growth regulators from fruit and leaf of Vitex rotundifolia. Z Naturforsch 59, 510-4. 